\title{
Tavuk Yumurtası Mikronükleus Testi
}

Haluk ÖZPARLAK ${ }^{1}$, Bülent ÇELIK ${ }^{1}$

ÖZET: Genotoksisite testleri içinde çok yaygın kullanılan yöntemlerden biri mikronükleus tekniğidir. Mikronükleus testleri içerisinde ise diğerlerine kıyasla daha yeni bir teknik Tavuk Yumurtası Mikronükleus Testi (Hen's Egg Test for Micronucleus Induction, HET-MN)'dir. HET-MN hayvan hakları ve etik açıdan kesinlikle uygun, in vitro ve in vivo deneyler arasına yerleştirebileceğimiz son derece basit, ucuz ve hızlı bir genotoksisite testidir. Ayrıca bu modelin sağladığı yüksek metabolik yetkinlik mutajen ve promutajenleri içeren ksenobiyotiklerin metabolik aktivasyonuna da imkân tanımaktadır. Bu makalede önce mikronükleus testlerinin çeşitleri, ardından HET-MN'nin uygulamasıyla ilgili güncel yayınlar derlenmiştir.

Anahtar Kelimeler: Eritrosit, genotoksisite, mikronükleus, tavuk embriyosu

\section{Hen's Egg Test For Micronucleus Induction (HET-MN)}

\begin{abstract}
One of widely used methods in genotoxicity tests is micronucleus technique. Hen's Egg Test for Micronucleus Induction (HET-MN) is a member of relatively new of micronucleus tests. HET-MN is an extremely simple, inexpensive and rapid genotoxicity assay which is positioned between pure in vitro and in vivo analysis, strictly in line with animal protection regulations and ethical aspects. Furthermore the high metabolic competency provided by this model enables metabolic activation of xenobiotics including mutagens and promutagens. In this article, recent publications about the kinds of micronucleus tests and then the application of HET-MN have been compiled.
\end{abstract}

Keywords: Chicken embryo, erythrocyte, genotoxicity, micronucleus

Selçuk Üniversitesi, Fen Fakültesi, Biyoloji Bölümü, Konya, Türkiye

Sorumlu yazar/Corresponding Author: Haluk ÖZPARLAK, hozparlak@selcuk.edu.tr 


\section{GİRIŞ}

Günümüz dünyasında insanoğlu yaşam ortamlarında mevcut çok fazla sayıda kimyasal ve fiziksel ajana gün geçtikçe daha fazla maruz kalmaktadır. $\mathrm{Bu}$ sebeple bu ajanların potansiyel genotoksik risklerini ve olumsuz etkilerini değerlendiren çalışmaların önemi gittikçe artmaktadır. Ayrıca yeni ilaçların ve diğer kimyasal maddelerin genotoksik etki bakımından taranması toksikolojik incelemelerin vazgeçilmez bir aşamasını teşkil etmektedir.

Genotoksisite, genotoksinlerin kromozom yapısında ve DNA yapısında meydana getirdiği hasarları içeren bir kavramdır. Bu hasarlar çoğunlukla DNA zincir kırıkları ile DNA eklentileri, gen mutasyonlar1 ve kromozom anormallikleridir. Bahsedilen hasarlar; birtakım genetik ve multifaktoryal hastalıklara, yaşlanmaya, doğum defektlerine, kısırlığa ve kansere yol açabildiği için, mutajen ve karsinojen maddelerin belirlenmesi ve olası tehlikelerinin en düşük düzeye indirilebilmesi halk sağlı̆ 1 için önemlidir. Toksikolojinin bir alt dalı olan genotoksisite, genetik hasarlara neden olabilecek ajanları araştırmaktadır. 1992 yılında yayınlanan Uluslararas1 Kanser Araştırmaları Ajansı (IARC) raporunda geniş yer bulan genotoksisite, DNA'da görülen doğrudan veya dolaylı etkiler olarak ifade edilmiştir (Yırtıcı, 2007). Canlının genetik materyali DNA'da hasarlara ve genetik değişimlere neden olan maddelere genel bir ifadeyle genetik zehirler veya genotoksinler denir (Vural, 2005). Genotoksik maddeler canlı organizmaların üzerinde etkilerini iki yolla gösterirler. Birincisi DNA üzerinde doğrudan (hardal gazı gibi biyotransformasyon yolağına girmeden DNA molekülünü alkilleyerek) ya da dolaylı olarak (mikotoksinler gibi doğrudan DNA'ya etki etmeyip oluşturdukları metabolitleriyle DNA'yı etkileyerek) hasarlar oluşturmak, ikincisi DNA onarım mekanizmasını bloke ederek (organik çözücüler gibi) DNA hasarlarının birikmesine neden olmaktır (Çavaş, 2004; Özdemir ve ark., 2015).

Genotoksisite testlerinde amaç genomu etkileyecek UV ve irradyasyon gibi etmenler, parazitler, sigara, ilaçlar, gıdalarda kullanılan katk1 maddeleri ve pestisitler gibi ajanların genotoksik etkilerinin belirlenmesidir. $\mathrm{Bu}$ testler ilaçların etkilerinin araştırılmasında, ilaçların piyasaya sürülmesinde ve piyasaya sürülen ilaçları kullananlarda genetik etkilerin belirlenmesinde kullanılır. Bazı hastalıklara özgü artan
DNA hasarlarının belirlenmesinde ve belirlenen hasarla hastalık arasında bir ilişkilendirmenin yapılabilmesinde, kanserle mücadelede, kanser duyarlılı̆̆ının tayininde ve takip edilmesinde genotoksisite test tekniklerine biyoizleme teknikleri olarak başvurulmaktadır (Preston et al., 1981; Choy, 2001; Jena et al., 2002; Mateuca et al., 2006; Özdemir ve ark., 2015).

Genotoksisite testlerinde hedef DNA molekülü olduğu için yapılan çalışma sonuçları insan sağlığıyla ilgili ortaya çıkabilecek sorunların belirlenmesinde kullanılabilmektedir. Bundan dolay1 bir türün DNA'sinda hasara neden olan bir maddenin farkl1 türden canlıların DNA'sında hasar oluşturabileceğini düşünmek mümkündür. Günümüzde genotoksik etkilerin incelenmesini amaçlayan mikroorganizmalar, bitkiler, böcekler ve omurgalı hayvanlar üzerinde uygulanabilen 200'ü aşkın test tekniği bulunmaktadır. Genel bir ifadeyle bir genotoksisite testinde istenilen temel özellikler ekonomik açıdan ucuz olması, uygulanmasının basit ve hizlı olması, genetik hasarların belirlenmesinde hassas ve etkili olmas1, etik kurallara uygun olması, diğer testlerle korelasyon göstermesi ve analiz için az sayıda örneğin yeterli olması şeklinde siralanabilir (Waters, 1988; Öcal, 2012). Genel olarak genotoksisite testleri a) Çevreden kaynaklı ya da mesleki nedenlerden dolayı sürekli bazı ajanlara maruz kalan bireylerin genetik yapılarının izlenmesi, hasarların boyutunun ve sebebinin incelenmesinde b) Yapay ya da kirletici ajanların genotoksik etkilerinin araştırılmasında c) Üretilerek çeşitli alanlarda insanların kullanımına sunulan ya da sunulması planlanan kimyasal içerikli maddelerin genotoksik ya da anti-genotoksik etkilerinin araştırılmasında ve belirlenmesinde d) Çeşitli hastalıklarla genetik hasarların ilişkilendirmesinde kullanılmaktadır (Griffiths et al., 2000; Gomez-Arroyo et al., 2000; Monarca et al., 2001; Laffon et al., 2001).

DNA'da hasarlara neden olan maddeler bununla birlikte canlıda doku hasarlarına, yaşlanmaya, bazı genetik hastalıklara, kanser gibi birçok hastalıklara sebep olmaktadır. Genotoksisite ve karsinojenite bağlantısı çeşitli çalışmalarla incelenmiş ve karsinojen olan birçok bileşiğin aynı zamanda genotoksik madde olduğu kanısına varılmıştır. Buradan da anlaşılmaktadır ki maddelerin genotoksik, karsinojenik ve mutajenik etkileri arasında kuvvetli bir bağ vardır. Bu bağlamda genotoksisite testlerinin endüstri alanında kimyasal maddelerin olası karsinojenik etkilerinin taranması amacıyla kullanılması gerekliliği de ortaya konmuştur 
(Purchase et al., 1978; Choy, 2001; Zeiger, 2004). Karsinogenezdeki genetik değişimlerin belirlenmesinde ve karsinojenlerin tanımlanmasında genotoksisite testlerinin önemi oldukça büyüktür. $\mathrm{Bu}$ sebeple maddelerin etkilerini belirlemek için çeşitli test teknikleri geliştirilmiştir. Genetik etkilerin tamamı hakkında bilgi verecek nitelikte tek bir test tekniği yoktur. Yani bir kimyasal madde birden fazla test tekniği kullanılarak incelenmelidir. Genotoksiste testleri uygulanırken in vitro ve in vivo testler birlikte uygulanmalıdır (Al-Sabti and Metcalfe, 1995; Aydın, 2007).

Genotoksisite testleri genotoksik maddelerin belirlenmesinde 1970 y1lından beri kullanılmakta olup her geçen gün yeni teknikler eklenmektedir. Günümüzde yaygın olarak kullanılan bu testlerde aşağıda belirtilen prokaryotik ve ökaryotik sistemler kullanılmaktadır.

I. Bakteriyal Testler: 1. Umu testi 2. SOS testi 3. Ames testi 4. E.coli testi 5. Mutotox testi.

II. Ökaryotik Testler: 1. Comet testi 2. DNA alkalin unwinding assay 3. Alkali DNA elituion assay 4. DNA tamir sentezi (UDS assay) 5. Maya testleri (Saccharomyces, Neurospora ve Aspergillus) 6. Drosophila mutasyon test sistemleri 7. Sperm aberasyon yöntemi 8. Kök ucu testi 9. Kromozom aberasyon testi 10. Kardeş kromatit değişimi (SCE assay) 11. Mikronükleus testi (MN Test) (Çakır, 2004; Cunny and Hodgson, 2004; Parlak ve ark., 2011; Öcal, 2012).

Genotoksisite testleri içerisinde yaygın bir şekilde kullanılan yöntemlerden birisi de mikronükleus (MN) testleridir. $\mathrm{Bu}$ makaleyle öncelikle $\mathrm{MN}$ testlerinin çeşitleri hakkında bilgi vermek amaçlanmıştır. Bunun yanısıra özellikle alternatif bir MN test yöntemi olan tavuk yumurtası mikronükleus test sisteminin (Hen's Egg Test for Micronucleus Induction- HET-MN) uygulanması hakkında bilgi vermek ve böylece bu testin kullanımının yaygınlaştırılmasına katkı sağlamak amaçlanmıştır.

\section{MATERYAL VE METOT}

$\mathrm{Bu}$ çalışma çok sayıda güncel literatür kullanılarak oluşturulmuştur. Bunlar içerisinde özellikle Wolf and Leupke (1997), Wolf et al. (2002), Wolf et al. (2003) ve Wolf et al. (2008)'in makaleleri güncel ve önemli çalışmalardır.

\section{BULGULAR VE TARTIŞMA}

\section{Mikronükleus (MN) ve MN Testleri}

Mikronükleus (Micronucleus, MN) 1 1̧̧1k mikroskobuyla görülebilen, bir hücrenin sitoplazmasında bulunan, hücrenin ana çekirdeğiyle benzer boyanan, incelenen hücrenin tipine bağlı olarak hücre çekirdeğinin üçte birinden büyük olmayan ve çoğunlukla yuvarlak veya hafif oval şekilli yapılardır. Bununla birlikte 1 şı mikroskobuyla görülemeyen, yalnızca elektron mikroskobuyla tespit edilebilecek kadar küçük MN'ler de olabilir. MN'ler tipik iki zardan oluşan bir nükleus zarfına, nükleer laminaya ve nükleus porlarına sahiptirler. Biyokimyasal açıdan yapısına bakıldığında MN'ler DNA sentezleme ve eğer nükleolus organizer bölgesine (Nucleolus Organizer Region-NOR) sahip bir kromozom parçası ise RNA, mRNA ve rRNA'da sentezleme yeteneğine sahiptirler (Müller and Streffer, 1994).

MN mitoz bölünmenin metafaz-anafaz geçişi esnasında oluşur. MN'ler, bir kromozomun kutuplara çekilmesi sırasında gerçekleşen anöjenik (kromozom kaybına sebep olan) bir olay sonucu tümüyle kaybı ya da klastojenik (kromozom kırığına sebep olan) bir olay sonucu asentrik (sentromersiz) bir parçasının kırılıp kardeş hücrelere ulaşamaması sonucu şekillenebilirler (Fenech et al., 1999). MN genelikle hücre siklusunun kontrolünü sağlayan genlerin eksikliğinden, kinetokorlardaki hatalardan, iğ ipliğindeki hatalardan, kromozom hasarlarından ve mitotik aygıtın diğer parçalarından oluşan ve ana çekirdek dışında tam kromozom veya asentrik kromozom fragmentlerinden oluşmaktadır. MN'lerin büyüklüğü ana çekirdeğin büyüklüğünün 1/3-1/16's1 arasında değişir. MN genellikle ana nükleustan ayrıdır ve aynı renkte boyanır. Şekil olarak genellikle yuvarlaktır ancak bazen badem ya da hilal şeklindede olabilir (Vanparys et al., 1990; Duffaud et al., 1997; Kirsch-Volders et al., 1997; Stopper and Müler, 1997; Choy, 2001; Demirel ve Zamani, 2002; Mateuca, 2006; Yrrtıc1, 2007).

MN oluşumları DNA'da meydana gelen kırıklar neticesinde oluşmaktadır ki bu kırıkların cinsi bazen tek zincir kırığı bazen de çift zincir kırığıdır. Tek zincir kırıkları hücrenin replikasyonu sırasında çift zincir kırığına dönüşebilir. Genellikle bir hücre içinde bir $\mathrm{MN}$ oluşumu görülürken genotoksik maddenin 
etkisine bağlı olarak MN sayısı iki veya daha fazla olabilmektedir (Fenech, 1985).

İyonizan radyasyon ve pek çok kimyasal mutajen, kromozomlarda büyük, çok sayıda ve çoğunluğu 1şı mikroskobuyla dagörülebilenyapısal bozukluğayol açar. Bu bozukluklar, DNA tamir teorisi ve iyonizan 1şınların kullanıldığı radyo biyolojide biyolojik dozimetri, klinik sitogenetik ve çeşitli maddelerin kimyasal ve elektromanyetik alanlar gibi fiziksel etkenlerin çevresel etkilerinin değerlendirilmesinde birçok pratik uygulama alanı olan testlerin temel teorisini şekillendirmektedir. "Asimetrik Olaylar" veya "Kararsiz Kusurlar" da denen kromozom bozukluklarında, kromatidlerin kromozomal mikrotubuluslara tutunma bölgeleri olan kinetokor ve sentromerleri oluşmaz. Böyle kromozom parçaları "Asentrik Fragmanlar" olarak da bilinirler. Hücre bölündüğünde bunların bazıları yeni oluşan hücre çekirdeğinin yapısına giremez ve ayrılarak sitoplazmada küçük, ekstra nükleusları yani MN'leri, tek başlarına veya diğer yapılarla birlikte şekillendirirler. Böyle MN'ler yeni hücrelerin sadece birinin ya da her ikisinin sitoplazmasında görülürler (Savage, 2000).

Bir hücrede bulunan asentrik fragman sayısıyla o hücrede oluşan mikronükleus sayısı arasında basit bir bağıntıkurulmasını engelleyenvekritik sayısal sonuçlara ulaşmayı zorlaştıran pek çok faktör bulunmakla birlikte; yapılan deneysel çalışmalar, bir etkenin genotoksik etkisinin hücrelerdeki MN bulunma sıklığında yani MN frekansında sebep olduğu sayısal artışla ortaya konulabileceğini göstermiştir. Bu bulguya dayanılarak, interfazdaki yani arafazdaki hücrelerde MN frekansının saptanması suretiyle gerçekleştirilen genotoksisite tespit yönteminin; daha kompleks ve daha çok zaman isteyen, metafaz safhasındaki kromozomlardaki (mitoz bölünmede) yapısal ve sayısal sapmaları tespit eden yöntemlerin yerini alabileceği ileri sürülmüş ve bu amaçla MN testleri geliştirilmiştir. Mutajen maddelerin genotoksik potansiyellerinin incelenmesinde ve özellikle de sayısal cevaplar gerektiğinde $\mathrm{MN}$ testi oldukça güvenilir bir yöntem olup; son derece mantıklı sonuçlar elde edilebilmektedir. Bununla birlikte, bu analiz sisteminde de pek çok analiz yönteminde olduğu gibi yeterli tecrübeye sahip olunmaması durumunda pek çok zorlukla karşılaşılabilmektedir (Savage, 2000).

MN frekans1, fibroblast kültürleri ve lenfosit kültürleri yanı sıra epitel hücresi döküntülerinde de tespit edilebilmektedir. Hatta doku kesitlerinde de MN sayımı yapılabileceği belirtilmektedir. Günümüzde MN yöntemi standart bir sitogenetik test olarak kabul görür hale gelmiştir. Standart mikronükleus testinde; etkisi incelenecek olan madde hücre kültürüne ilave edilir. Daha sonra, mitojen (Örneğin; phytohemagglutinin, PHA) ilavesiyle mitoz bölünmeye sevk edilen hücreler, mitozun karyokinez aşamasını tamamladiktan sonraki kritik bir evrede sitokinezi (kardeş hücrelerin nükleuslarının şekillenmesini takip eden sitoplazma bölünmesi) durduran bir maddenin (Örneğin; Cytochalasin B, Cyt-B) ilave edilmesinden sonra iki nükleuslu (dikaryotik) hücreler oluşturulur. Böyle hücrelerde yapılan incelemede oluşan mikronükleuslar daha kolayca tanınabilirler. Sitogenezis-Blok Mikronükleus (Cytokinesis-Block Micronucleus, CBMN) testiyle kromozom kırıkları, kromozom kayıpları, nondisjunction, nekroz, apoptozis ve sitostazis gibi bozukluklar da belirlenmektedir. Bunun yanı sıra bu yöntemle mukoza epitel hücreleri (ağız, burun, bronş ve ürogenital sistemin eksfolyatif hücreleri gibi) de incelenebildiğinden yöntem, çeşitli kimyasal ve fiziksel ajanların sitogenetik etkilerinin belirlenmesi amaciyla eksfolyatif sitolojide de yaygin biçimde uygulanan bir teknik haline gelmiştir. Bununla birlikte mikronükleuslar, epitelin yüzey kısmında bulunan hücrelerde gözlenmezken bazal kısmında bulunan hücrelerde gözlenmektedir (Müller and Streffer, 1994; Fenech, 2000; Kirsch-Volders and Fenech, 2001; Fenech et al., 2003). Kromozomlardaki yapısal ve sayısal bozuklukların belirlenmesinde en çok kullanılan, ucuz, basit ve hızlı bir yöntem olan mikronükleus testi, OECD (Organization for Economic Cooperation and Development), ICH (International Conference on Harmonization), EU (European Union) ve USEPA (United State Environmental Protection Agency) tarafindan bilimsel bir yöntem olarak kabul edilmiştir (USEPA 1996, Wolf et al., 2002; Wolf et al., 2003). MN test tekniğinin etkili bir metot olmasının başlıca nedenleri farklı hücre tiplerine uygulanabilmesi, sayımlarının kolay yapılabilmesi, elde edilen verilerin fazla olmasindan dolayı istatitiksel olarak testin güvenirliliğinin artmasıdır (Rajaguru et al., 1999). Testin uygulanmasında dikkat edilmesi gereken noktalardan birincisi incelenecek maddelerin konsantrasyonları (en az üç konsantrasyon), ikincisi çalışmada kullanılan çözücü veya taşıyıcının kullanıldığı negatif kontroller ile 
mitomisin C (Mitomycin C, MMC) veya siklofosfamid (Cyclophosphamide, CP) gibi pozitif kontrol gruplarının mutlaka oluşturulmasıdır (GPT, 2006).

MN testiyle genotoksik ajanların mutajenik etkileri tespit edilirken, kullanılan test gruplarındaki $\mathrm{MN}$ oranı kontrol gruplarından daha fazla çıkar ise test edilen maddenin mutajenik olduğuna, kontrol grubuyla karşılaştırıldığında bir farklılık meydana gelmemişse mutajenik olmadığına karar verilir. Eğer uygulanan madde mevcut MN oranında azalmaya sebep oluyorsa maddenin anti-mutajenik olduğu anlaşılır. Ayrıca uygulanan maddenin toksik dozunun artmasıyla birlikte artan MN oluşumuna karşın, sonradan bir azalma meydana geliyorsa o zaman da aşırı toksik dozdan hücre ölümlerinin gerçekleşmeye başladığı düşünülebilir (AlSabti, 1986; Heddle et al., 1991).

Hücrede spontan olarak da MN oluşabilir. Spontan MN sayısı hücre bölünmesinin ve asentrik kromozom parçalarının oluşma sıklığına bağlıdır. Spontan MN oluşumuna ikitip mutasyon neden olmaktadır. Bunlardan birincisi, kinetokor proteinlerinde, sentromerde oluşan mutasyonlar ve anafazda kromozom kaybı ya da eşit olmayan kromozom dağılımına yol açan iğ iplikçiklerindeki mutasyonlardır. İkincisi ise, asentrik kromozomların oluşumuna neden olan, çevresel mutajenlere maruz kalmanın bir sonucu olarak tamir edilemeyen DNA zincir kırıklarıdır (Alakoç, 2010).

MN testi kromozomlar üzerinde etkili olan fiziksel ve kimyasal maddelerin genotoksik ve karsinojenik potansiyellerinin belirlenmesinde kullanılmaktadır. Piyasaya sürülmeden önce ilaçların kanserden korunmada, kanseri izlemede, toksik etkilerin araştırılmasında ve güvenirliliğinin belirlenmesinde kullanılan biyoizlem bir test olarak kullanılmaktadır. MN testi kanser tanısinın konulması ve takibinin yapılmasında yaygın olarak kullanılmaktadır. Hücrede meydana gelen morfolojik bozukluklar, kromozom kırıkları, ileride tümöre dönüşebilecek lezyonlar kanser göstergesidir. Bu yüzden karsinojenlere maruz kalmış bireylerin kanser risklerinin belirlenmesinde kullanılmaktadır. Ayrıca bu yöntem sigara, gıda katk1 maddeleri, pestisitler, iyonize radyasyon, mikrodalga 1şınlar gibi buna benzer birçok kimyasal ve fiziksel etkenlerin değerlendirilmesinde de yaygın olarak kullanılmaktadır (Preston et al., 1981; Choy, 2001; Mateuca et al., 2006).
Lenfosit kültürlerindeki in vitro araştırmaların yanı sıra MN tekniği, in vivo olarak da kullanılmakadır. Memeliler üzerinde gerçekleştirilen in vivo $\mathrm{MN}$ testi, in vitro ortamlardaki test sistemlerinde tespit edilen mutajenik etkinin daha ayrıntılı incelenmesine ve test edilen maddenin in vivo farmakokinetiği, metabolizması ve DNA onarım süreçleri gibi unsurların analiz edilmesine de imkan vermektedir. Çoğunlukla tercih edilen in vivo $\mathrm{MN}$ testi, memeli eritrositlerindeki MN frekansının tespit edildiği yöntemdir. Genellikle bu test kemik iliğindeki veya periferal kan hücrelerindeki ya da her ikisindeki eritrositlerin analizlerinin yapilarak, test edilen maddenin kromozomal hasara sebep olup olmadığının belirlenmesinde kullanılır. Pekçok kimyasal bileşiğin uygulanması hematopoietik hücrelerin bölünme anında kromozom hasarına veya mitoz bölünmenin sekteye uğramasına sebep olmaktadır. Eritropoezisde son mitoz bölünmenin ardından kemik iliğindeki eritroblastlar polikromatik eritrositlere dönüşürken nükleuslarını kaybetmekte ve bu esnada oluşan kromozomal hasar hücrenin sitoplazmasında $\mathrm{MN}$ oluşumuna sebebiyet vermektedir. $\mathrm{MN}$ ihtiva eden tamamen olgunlaşmamış polikromatik eritrosit frekansındaki artma kromozomal hasarın veya anafaz gecikmesi sonucunda oluşan sitogenetik hasarın belirtecidir. Çoğunlukla in vivo MN yöntemi kullanılan araştırmalarda periferal kan daha stabil olduğundan daha çok tercih edilmektedir (Von Ledebur and Schmid, 1973; MacGregor et al., 1987; Mavournin et al., 1990; Üstün, 2007).

Bitkiler üzerinde de MN testi uygulanmaktadır. Örneğin, Vicia faba bitkisinin kök ucu hücrelerinde fenolün toksik etkileri $\mathrm{MN}$ testiyle belirlenmeye çalışılmıştır. Yapılan çalışma neticesinde fenolün Vicia faba bitkisinin kök ucu hücrelerinde MN oluşumuna neden olduğu belirlenmiştir (Çavuşoğlu ve ark., 2008).

Son yıllarda MN testinin avantajlarından dolayı balıklardaki kromozomların yapısal ve sayısal hasarlarının belirlenmesinde de kullanılmaya başlanmıştır. Ancak balıkların kromozomlarının memeli kromozomlarına oranla küçük olması balıklarda küçük MN oluşumlarına neden olmaktadır. Balıklarda eritrositlerdeki MN'lerin yanı sıra solungaç epitelindeki MN'ler de incelenmektedir. Örneğin, Pyrethroid grubundan Cypermethrin'in Oreochromis niloticus türü üzerindeki genotoksik etkilerinin belirlenmesi 
amacıyla solungaç epitel hücrelerine mikronükleus testi uygulanmış ve doz artışına bağlı olarak mikronükleus frekansında anlamlı artışlar tespit edilmiştir (Ergene ve ark., 2001).

Amfibilerin eritrositlerinde nükleus bulunması MN testinin kullanımını daha kullanışı hale getirmiştir. Örneğin, Rana catesbeiana iribaşları üzerinde yapılan $\mathrm{MN}$ testleri sayesinde iribaşların su kirliliğininde model organizma olarak kullanılabileceği önerilmektedir (Campana et al., 2003). Portekiz'in küçük bir kasabasındaki uranyum madeni gölünden ve bu gölün uzağındaki referans bölgeden alınan Rana perezi türü kurbağaların dokularındaki histopatolojik değişimler ve eritrositlerdeki nükleer anomaliler incelenmiştir. Çalışmada kirli bölgede görülen eritrosit nükleer anomalilerin (loblu, mikronükleuslu vb.) referans bölgeye göre önemli derecede yüksek çıktı̆̆ 1 bildirilmiştir (Margues et al., 2009).

$M N$ ve nükleus anormalliklerinin değerlendirildiği bir diğer canlı grubu da kaplumbağalardır. Örneğin, rehabilitasyon merkezlerinde tedavi altında bulunan yaralı Caretta caretta'ların perifer kanlarında bazı kimyasal ajanların sebep olduğu genotoksik etkiler MN ve nükleus anormallikleri belirlenerek tespit edilmiştir (Ergene ve ark., 2012). Azerbaycan'da kontamine olmuş sulak alanlarda yaşayan sucul kaplumbağaların (Emys orbicularis ve Mauremys caspica) kromozom düzeyindeki zararlarını değerlendirmek için $\mathrm{MN}$ testi ve flow sitometri yöntemi (Flow Cytometry MethodFCM) kullanılmış ve MN testiyle kirliliğin genotoksik düzeyde olduğu tespit edilmiştir (Matson et al., 2005).

MN testinin bir başka modifikasyonu 5-7 günlük civcivlerin kemik iliği ve perifer kan eritrositleri üzerinde gerçekleştirilmiş ve başta pestisitler olmak üzere çeşitli kimyasal bileşiklerin genotoksik etkisi bu yöntemle test edilmiştir (Bhunya and Jena, 1992; Jena and Bhunya, 1992; Bhunya and Jena, 1993; Jena and Bhunya, 1994; Bhunya and Jena, 1996; Özparlak ve ark., 2011). Bu test yöntemini kullanan araştırıcılar civciv in vivo $\mathrm{MN}$ test sistemin memeli test sistemlerine alternatif olabileceğini vurgulamışlardır (Bhunya and Jena, 1992; Giri et al., 2002).

Son zamanlarda yapilan genotoksisite çalışmalarında farklı canlı organizmalarda ve farklı dokularda ana nükleusta genotoksik maddelerin sebep olduğu şekilsel bazı bozuklukların olduğu belirlenmiştir. $\mathrm{Bu}$ sebeple $\mathrm{MN}$ testlerinde $\mathrm{MN}$ oranı yanı sıra genotoksisitenin bir indikatörü olarak nükleus anormallikleri de belirlenebilmektedir. $\mathrm{Bu}$ bozukluklar binükleus, tomurcuklu nükleus, loplu nükleus ve çentikli nükleus gibi sıralanabilir (Ayllon and Garcia-Vazquez, 2000; Çavaş and Gözükara 2003; Özparlak, 2006; Könen, 2007; Aymak, 2010). Bir hücre içerisinde çift nükleus bulundurma durumu sitotoksik etmenlerin göstergesi olarak kabul edilebilir. Nükleus anormalliklerinden biri olan çentikli nükleuslarda ise nükleus zarında içe doğru bir çöküntü meydana gelir ve çentik oluşur. Çentik içerisinde kromatin bulundurmaz. Tomurcuklu nükleusta nükleusun zarından dış kısma doğru çıkıntılar vardır. Kromatin içeren bu çıkıntılar tomurcuk görünümündedirler. Loblu nükleusta tomurcuktan daha büyük ve daha fazla lob söz konusudur. Binükleus yapısı ise aynı hücre içerisinde iki tane nükleus bulunma durumudur (Könen, 2007).

Nükleusta tomurcuklanma hücre döngüsünün $\mathrm{S}$ evresinde oluşur ve meydana gelen tomurcuklar MN ile aynı morfolojik görünümdedirler. İkisi arasındaki fark oluşum safhalarına bağlı olarak, lob ve tomurcukların ana nükleusa büyüklüğü ve kalınlığı değişebilen bir nükleoplazmik köprüyle bağlı olmasıdır. Nükleusta tomurcuklanma ve meydana gelen mikronükleusun hücreden atılmasinın ne kadar sürdüğü hala bilinmemektedir (Shimizu et al., 1998).

\section{Tavuk Yumurtası Mikronükleus Testi (Hen's} Egg Test For Micronucleus Induction, HET-MN)

Literatüre bakıldığında tavuk embriyolarının embriyotoksisite ve teratojenite çalışmalarında yaygın bir şekilde kullanıldığı görülmektedir. Jelinek (1977) döllü tavuk yumurtası kullanarak Tavuk Embriyotoksisite Belirleme Testini (Chicken Embryotoxicity Screening Test, CHEST), Luepke (1985) Tavuk Yumurtası Korioallantoik Membran Testini (Hen's Egg Test-Chorioallantoic Membrane, HET-CAM), Kemper and Luepke (1986) Tavuk Yumurtası Testini (Hen's Eggs Test, HET), Rosenbruch and Holst (1990) HET-CAM'a alternatif başka bir testi, Nishigori et al. (1992) Döllü Tavuk Yumurtas1 Tarama Testini (Hen's Fertile Egg Screening Test, HEST), Neumann et al. (1997) ise tavşan göz irritasyon 
testine (Draize Test) alternatif olarak PHET'i (Photo Hen's Egg Test) geliştirmişlerdir. Bu test yöntemleri kullanılarak yapılmış çok sayıda araştırma mevcut olup tavuk embriyoları yoğun bir şekilde kullanılmaya devam etmektedir (Özparlak, 2015).

Wolf and Leupke (1997) ise kuluçkaya alınan döllü tavuk yumurtalarında gelişen embriyoların periferal kan eritrositlerinde $\mathrm{MN}$ oluşumunu rapor ederek, Tavuk Yumurtası Mikronükleus Testi (Hen's Egg Test for Micronucleus Induction, HET-MN) olarak isimlendirdikleri yöntemi geliştirmişler ve daha sonra yaptıkları araştırmayla (Wolf et al., 2002) bu yöntemde modifikasyonlar yapmışlardır. Son derece hızlı, basit ve ucuz bir genotoksisite testi olan bu metod, etik açıdan ve hayvan hakları açısından da makul görülmektedir. HET-MN'nin gerçekleştirildiği evrede beyin aktivitesi başlamazken, yüksek bir metabolik aktivitenin bulunması bu testi hayvan kullanılmayan diğer genotoksisite çalışmalarına da üstün kılmaktadır. Bununda ötesinde korio-allantoik membranın sinirlerle temasinın olmaması ve ac1 reseptörlerinden yoksun olması testin olumlu yanlarındandir. Yumurtadaki embriyo ortamının fizyolojik koşullara daha yakın olması bu testi in vitro testlere de üstün kılmaktadır. Tavuk embriyosunun dolaşımdaki eritrosit hücre kompozisyonunun ergin memelilerdeki kemik iliği hücre kompozisyonuna benzemesi, fare periferal kanında $\% 5$ oranında polikromatik eritrosit bulunurken 11 günlük tavuk embriyolarında bu oranın \%25-50 olması, ayrıca çoğu memelide anormal eritrositleri elimine eden dalağın tavuk embriyosunda HET-MN'nin gerçekleştirildiği evrelerde tamamıla gelişmemesi ve dolayısıyla MN'lerin dolaşımda yoğunlaşması bu yöntemin diğer önemli özellikleridir. Bu yöntemin bilgisayarlı resim analiz sistemleriyle çok hızlı gerçekleştirilebileceği de vurgulanmıştır (Wolf and Leupke, 1997; Wolf et al., 2002; Wolf et al., 2003).

Wolf et al. (2002) HET-MN'yi modifiye etmek için siklofosfamid (Cyclophosphamide, CP) ve 7,12-dimethyl-benz[ $\alpha]$ anthracene (DMBA) ile yaptıkları çok sayıdaki denemelerde, test edilecek solüsyonları kuluçkanın 8., 9. veya 10. günlerinde, birinci yöntemde yumurtanın sivri ucundan albümine hipodermik iğne ile enjekte etmişler, ikinci yöntemde ise hava kamarasını açarak kabuk altı zarı üzerine pipetle vermişlerdir. Uygulamaları takiben kuluçkanın
24, 48 veya 72. saatlerinde embriyolardan (Arteria Umbilicalis Sinistra'dan) kan örnekleri alarak, frotilerini hazırlayıp, modifiye May-Grünwald Giemsa yöntemiyle boyamışlar ve eritrositlerdeki MN oranlarını belirlemişlerdir. Hava kamarasına yapılan enjeksiyonlar sonucunda albümine kıyasla daha yüksek oranda MN gözlemişlerdir. Ayrıca 8. günde yapılan enjeksiyondan sonraki 72. saatte alınan kan örneklerindeki $\mathrm{MN}$ oranının en yüksek düzeyde olduğunu, diğer saatlerdeki oranların ise daha düşük olduğunu tespit etmişlerdir. $\mathrm{Bu}$ sonuçlar 1şığında HET-MN için hava kamarası yöntemiyle, test solüsyonunun kuluçkanın 8 . gününde enjekte edilerek 11. günde kan örneklerinin alınması ideal olarak kabul edilmiştir (Wolf et al., 2002).

Tavuk embriyolarında embriyonik dönemin 4. gününde karaciğer farklılaşması olmakta ve bu günden sonra karaciğerin detoksifikasyon mekanizmaları çalışmaya başlamaktadır (Hamilton et al., 1983). Wolf and Leupke (1997), memeli embriyosunun aksine, tavuklarda karaciğerin erken farklılaşmasına bağlı olarak, tavuk embriyosunun gelişiminin erken evrelerinde de yoğun bir metabolik aktivasyon mevcut olduğunu belirtmişler, böylece kuluçkanın 8. gününde enjeksiyon yapılarak promutajenlerin de genotoksik etkilerinin belirlenebildiğini vurgulamışlardır.

Wolf et al. (2002) ve Wolf et al. (2003) embriyonik dönemdeki periferal eritrositleri iki hücre hattına ayırmışlardır (Şekil 1). E I olarak adlandırdıkları gruba primitif eritrositleri (primary/primitive erythrocytes), E II olarak adlandırdıkları gruba sekonder eritrositleri (secondary/definite erythrocytes) dâhil etmişlerdir. E II (sekonder eritrositler) eritroblastları, proeritroblastları, erkenpolikromatik,ortapolikromatikvegeçpolikromatik eritrositleri ve olgun normokromatik eritrositleri ihtiva etmektedir. E I hücreleri daha büyük boyutları, düşük nükleus-sitoplazma oranları ve yuvarlak yapıları ile karakteristiktir. E II hücreleri ise büyük, yuvarlak, bazofilik ve büyük nükleuslu proeritroblastlardan başlayıp, oval şekilli, normokromatik, küçük ve yoğun nükleuslu olgun hücrelere kadar olan eritroid seri hücrelerini kapsamaktadır (Wolf and Luepke, 1997; Wolf et al., 2002). Embriyonik dönemdeki hücre tiplerinin sinıflandırılmasında ayrıca Bruns and Ingram (1973) ve renkli literatür olarak Lucas and Jamroz (1961) referans olarak kabul edilmektedir. Bu hücrelerin çoğunluğu Şekil 1'de görülebilir. Wolf et al. (2002) 
çalışmalarında primitif eritrositlerde (E I) kuluçkanın 6. ve 7. günleri arasında proliferasyon sona erdiği için kuluçkanın 8. günü enjeksiyon yapılan çalışmalarda bu hücrelerin mutajenik muameleden etkilenmediğini, $\mathrm{MN}$ oluşturamadığını ve $\mathrm{MN}$ oranı bakımından kontrol grubundan fark göstermediğini tespit etmişlerdir. $\mathrm{Bu}$ sonuçlara dayanarak MN'li E II (sekonder eritrositler,
MNEII) hücrelerinin tüm olgunlaşma evreleri (eritroblastlar, proeritroblastlar, erken polikromatik, orta polikromatik ve geç polikromatik eritrositleri ve olgun normokromatik eritrositler) dâhil olmak üzere total frekans1 HET-MN'de genotoksisitenin parametresi olarak kabul etmişlerdir.

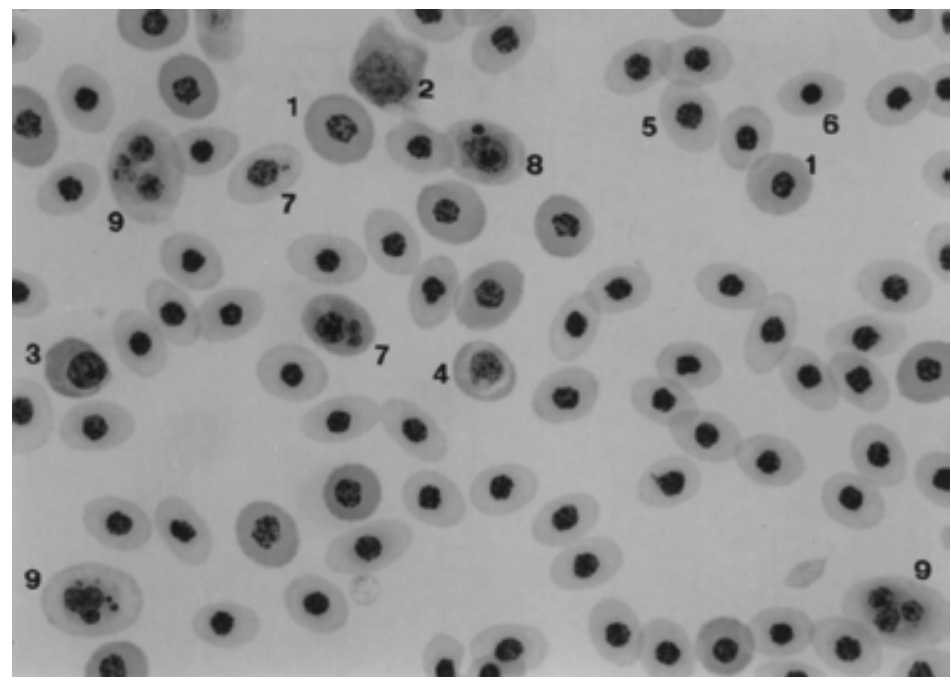

Şekil 1. Kuluçkanın on birinci günündeki tavuk embriyolarının (hava kamarası yoluyla $3 \mathrm{mg}$ /yumurta siklofosfamit uygulamasından 48 saat sonra) perifer kanından hazırlanan ve modifiye May-Grünwald Giemsa yöntemiyle boyanmış bir kan frotisinin 1şık mikroskobik görünümü. ${ }^{1}$ Primitif normokromatik eritrosit, ${ }^{2}$ Şekil bozukluğu olan bir eritroblast (bu hücre tipi sadece yüksek dozda veya uzun süreli siklofosfamit uygulamalarında görülebilir), ${ }^{3}$ Çok az şekil bozukluğu olan bir erken polikromatik eritrosit, ${ }^{4}$ Çok az şekil bozukluğu olan bir orta polikromatik eritrosit, ${ }^{5} \mathrm{Geç}$ polikromatik eritrosit, ${ }^{6}$ Normokromatik eritrosit, ${ }^{7}$ Mikronükleuslu polikromatik eritrosit, ${ }^{8}$ Mikronükleuslu eritroblast, ${ }^{9}$ Nükleus anomalisi olan bir polikromatik eritrosit (Wolf and Leupke (1997)'den alınmıştır)

Wolf and Luepke (1997), Wolf et al. (2002) ve Wolf et al. (2003)'nın HET-MN'de uyguladıkları modifiye May-Grünwald Giemsa yöntemi şu şekilde özetlenebilir. Kan frotileri başlangıçta $3 \mathrm{dk}$ filtre edilmiş May-Grünwald'la boyanır. Ardından froti üzerine boyayla aynı hacimde $0.1 \mathrm{M}$ disodyumsitrat $/ \mathrm{NaOH}$ tamponu (pH's1 5.2) eklenir. Metalik bir parlaklık görülünceye kadar bununla birlikte 5 dk'yı aşmayacak şekilde boyamaya devam edilir. Preparatlar saf suyla yıkanır. Ardından preparatlar $0.1 \mathrm{M}$ disodyumsitrat/ $\mathrm{NaOH}$ tamponunda ( $\mathrm{pH}$ 's1 5.2) hazırlanmış ve filtre edilmiş \%30'luk Giemsa'yla $20 \mathrm{dk}$ boyanır ve saf suyla birkez daha y1kanır. Wolf and Luepke (1997), Wolf et al. (2002) ve Wolf et al. (2003), boyanan preparatlar 1şık mikrosbuyla değerlendirilirken her yumurta için genellikle 1000 veya daha fazla sayıda EII hücresi incelemiş ve bu hücrelerdeki mikronükleus frekansını belirlemişlerdir. Araştırıcılar EII hücrelerindeki nükleusa benzer görünümlü ve aynı boyanma özelliğine sahip, yuvarlak-oval şekilli, sınırları belirgin, üç boyutlu ve nükleus boyutunun üçte ikisini geçmeyen yapıları MN kabul etmişlerdir.

Wolf et al. (2002) HET-MN'yi modifiye etmek için, white leghorn (strain Lohmann selected, LSL) damızlıklara ait her grupta 5-6 yumurta kullanarak ve kuluçkanın 8. günü test solüsyonlarını enjekte ettikleri ve kuluçkanın 11. günü kan örneği alarak yaptıkları çalışmalarında, $100 \mu \mathrm{l}$ bidistile su içerisindeki $50 \mu \mathrm{g} /$ yumurta CP dozunu üç denemede kullanmışlardır. E II hücrelerinde birinci denemede \%13.2, ikinci denemede $\% 7.3$ ve üçüncü denemede $\% 9.3$ oranında mikronükleus gözlemişlerdir. Wolf et al. (2003) ve Wolf et al. (2008) daha sonraki HET-MN çalışmalarında pozitif kontrol amacıyla ideal kullanımı sebebiyle suda çözünen CP kullanmışlardır. 
Son yıllarda HET-MN yöntemiyle yapılan güncel diğer çalışmalar ise şu şekilde sıralanabilir. Wolf et al. (2003) HET-MN yöntemini kullandıkları çalışmalarında kanserojen üç maddenin N-nitrozodimetilamin (NDMA), N-Nitrozodietil amin (NDEA), N-Nitrozodietanol aminin (NDELA) genotoksik etkilerini araştırmışlardır. NDMA ve NDEA maddeleri test sisteminde bariz bir şekilde pozitif sonuç vermiştir. NDMA literatüre uyumlu bir şekilde bu test sisteminde NDEA'dan çok daha yüksek mutajenite göstermiştir. Bu iki bileşiğin HET-MN sistemindeki duyarlılı̆̆ 1 göz önüne alındığında, kemirgen $\mathrm{MN}$ test sistemlerinde daha önceki yayınlanmış sonuçlarla kıyaslandığında büyük ölçüde daha duyarlıdır. NDELA'nın eritrosit oluşumu üzerine olumsuz etki göstermeksizin bu test sisteminde non-mutajenik olduğunu bariz bir şekilde teyit etmişlerdir. Wolf et al. (2003) alternatif bir genotoksisite test sistemi olarak HET-MN yönteminin kullanılmasını diğer hayvan testlerinden elde edilen yayınlanmış verileri destekleyebileceğini vurgulamışlardır. Çünkü HET$\mathrm{MN}$ in vitro genotoksisite testleriyle kıyaslandığında fizyolojik olarak in vivo testlere daha yakındır. Ayrıca daha fazla lokal ve sistemik etkilerin gözlenmesine olanak sağlamıştır.

Wolf et al. (2008), HET-MN yöntemiyle çok sayıda maddeyi [epirubicine (EPI), cadmium chloride (CD), cytarabine (AraC), acrylamide (ACM), methotrexate (MTX), dipotassium monochromate (DPC) ve acetylamino-fluorene (2-AAF)] test etmişler ve bu maddelerin pozitif sonuç verdiğini, ayrıca sonuçlarının daha önce yapılmış diğer genotoksisite test sonuçlarıyla uyumlu olduğunu tespit etmişlerdir. Bunun yanı sira üç maddenin de [azorubin (E122), orange $\mathrm{G}$ (OG) ve starch (STRC)] negatif sonuç verdiğini bildirmişlerdir. $\mathrm{Bu}$ çalışmalarında Wolf et al. (2008), HET-MN'yle daha önce yaptıkları tüm çalışmaların sonuçlarını da bir araya getirmişlerdir. Negatif kontrol (çözücü) grubunda toplam 445 yumurtadan 556500 eritrositte $\% 0.87 \pm 0.87$ oranında MNEII hücresi, $0.05 \mathrm{mg} /$ yumurta $\mathrm{CP}$ (pozitif kontrol grubu) uyguladikları toplam 223 yumurtadan 249250 eritrositde $\% 12.4 \pm 6.8$ oranında MNEII hücresi rapor etmişlerdir.

Özparlak (2008), organik insektisit fipronilin genotoksik etkilerini belirlemek amaciyla HETMN testi uygulamış, fipronil uygulanan gruplarda istatistiksel olarak önemli düzeyde mikronükleus artışı olmadığını tespit etmiştir. Ayrıca fipronilin diğer genotoksisite testlerinde de negatif sonuç verdiğini ve bunların HET-MN'den elde edilen sonuçlarla uyumlu olduğunu vurgulamıştır.

Greywe et al. (2012), çok sayıda genotoksik ve genotoksik olmayan bileşiği biri Osnabrueck Üniversitesi'nde ve diğeri Henkel AG\&Co'da olmak üzere iki ayrı laboraturda HET-MN yöntemiyle test etmişler ve aynı sonuçları bulmuşlardır. Ayrıca elde ettikleri sonuçların in vivo ve in vitro test sistemleriyle elde edilen sonuçlarla uyumlu olduğunu ve HET-MN yönteminin mevcut test yöntemlerine yardımcı olarak umut verici olduğunu vurgulamışlardır.

$\mathrm{Bu}$ yöntemle ilgili yapılan son çalışmada ise Hothorn et al. (2013) HET-MN için istatistiksel bir model (Freeman-Tukey'in karekök transforme edilmiş verilerle modifiye Williams modeli) önermişlerdir. $\mathrm{Bu}$ çalışmalarıyla, önceki çalışmalardaki her doz grubu için altı yumurta kullanımını ve her yumurta için 1000 hücrenin değerlendirilmesinin uygun olduğunu teyit etmişlerdir.

\section{SONUC}

Son yıllarda kanser vakalarının ve genetik hastalıkların sayısında ciddi yükseliş görülmektedir. Bahsedilen hastalıkların sebepleri spontan mutasyonlar olarak kabul edilse de, yaşadığımız ortamlarda devamlı maruz kaldığımız çevre kaynaklı kimyasal ve fiziksel ajanların olası etkileri ihmal edilemeyecek kadar çoktur. $\mathrm{Bu}$ sebeple mutajenlerin genotoksisite yönünden incelenmesi ve genotoksik potansiyele sahip olanların tespit edilerek gerekli tedbirlerin alınması gerekmektedir. Bunun içinde genotoksisite testlerinin kullanımları yaygınlaştırılmalı ve geliştirilmelidir. $\mathrm{Bu}$ testlerin yaygın bir şekilde kullanımıyla insanların ksenobiyotiklere karşı gösterecekleri genetik cevabın önceden tespit edilmesi, kanser gibi hastalıkların ve metabolizma bozukluklarının klinik belirti vermeden taranarak yatkın insanların belirlenmesi ve gerekli önlemlerin alınması gerçekleșebilecektir. Genotoksisite testlerinin yaygınlaştırılmasıyla insan sağlığı ve yaşam kalitesinin artması bilim dünyasının başlıca hedeflerindendir. Test edilecek ksenobiyotiklerin metabolik aktivasyonuna imkân sağlayan, nükleus 
anormalliklerinin de değerlendirilebildiği, hayvan hakları ve etik açıdan uygun, ucuz, basit ve hızlı bir genotoksisite testi olarak HET-MN, memeli test sistemlerine tek başına alternatif olamasada, memelilerle yapılacak çalışmalarda kullanılacak olan hayvan ve deneme sayısını azaltacağı için her geçen gün daha çok önem kazanacaktır.

\section{KAYNAKLAR}

Alakoç C, 2010. Gazaltı kaynağından çıkan gazlara maruz kalan kişilerin periferal kan lenfositlerindeki mitotik indeks, replikasyon indeksi ve mikronükleus parametrelerinin değerlendirilmesi. Bozok Üniversitesi Fen Bilimleri Enstitüsü, Yüksek Lisans Tezi, Yozgat.

Al-Sabti K, Metcalfe CD, 1995. Fish micronuclei for assessing genotoxicity in water. Mutation Research, 343: 121-135.

Al-Sabti K, 1986. Comparative micronucleated erythrocyte cell induction in three cyprinids by five carcinogenic-mutagenic chemicals. Cytobios, 47: 147-154.

Aydın SA, 2007. Fluniksin megluminin genotoksisitesinin in vitro ve in vivo/in vitro mikronükleus testleriyle değerlendirilmesi. İstanbul Üniversitesi Sağlık Bilimler Enstitüsü, Doktora Tezi, İstanbul.

Ayllon F, Garcia-Vazquez E, 2000. Induction of micronuclei and other nuclear abnormalities in European minnow Phoxinus phoxinus and mollie Poecilia latipinna: an assessment of the fish micronucleus test. Mutation Research, 467: 177-186.

Aymak C, 2010. Mersin bölgesinde yaşayan Rana ridibunda pallas, 1771 (Ranidae, Ampibia)'nın mikronükleus test yöntemi ile genotoksik etkilerinin ve ağır metal kirliliğinin tespit edilmesi. Mersin Üniversitesi Fen Bilimleri Enstitüsü, Doktora Tezi, Mersin.

Bhunya SP, Jena GB, 1993. Studies on the genotoxicity of monocrotophos, an organophosphate insecticide, in the chick in vivo test system. Mutation Research, 292: 231-239.

Bhunya SP, Jena GB, 1996. Clastogenic effects of copper sulphate in chick in vivo test system. Mutation Research, 367 (2): 57 63.

Bhunya SP, Jena GB, 1992. Genotoxic potential of the organochlorine insecticide lindane ( $\gamma$-BHC): An in vivo study in chicks. Mutation Research, 272: 175-181.

Bruns GAP, Ingram VM, 1973. The erythroid cells and haemoglobins of the chick embryo. Philosophical Transactions of the Royal Society, 266: 225-305.

Campana MA, Panzeri AM, Moreno VJ, Dulout FN, 2003. Micronuclei induction in Rana catesbeiana tadpoles by the pyrethroid insecticide lambda-chalothrin. Genetics and Molecular Biology, 26: 99- 103.

Choy WN, 2001. Genetic Toxicology and Cancer Risk Assessment, Marcel Dekker, New York, 406 p.

Cunny H, Hodgson E, 2004. Toxicity Testing, In: Hodgson, E. (ed.), A Textbook of Modern Toxicology, John Wiley \& Sons, Inc., USA, p. 353-397.

Çakır Ş, 2004. Bazı organik fosforlu insektisitlerin Drosophila melanogaster'in yaşama yüzdesi üzerine etkisi. Gazi Üniversitesi Gazi Eğitim Fakültesi Dergisi, 24(3): 71-80.
Çavaş T, Ergene-Gözükara S, 2003. Micronuclei, nuclear lesions and interphase silver-stained nucleolar organizer regions (AgNORs) as cyto-genotoxicity indicators in Oreochromis niloticus exposed to textile mill effluent. Mutation ResearchGen Tox En, 538: 81-91.

Çavaş T, 2004. Endüstriyel atıkların genotoksik etkilerinin mikronükleus ve AgNOR analiz teknikleri kullanılarak insitu ve laboratuvar koşulları altında araştırılması. Mersin Üniversitesi Fen Bilimleri Enstitüsü, Doktora Tezi, Mersin.

Çavuşoğlu K, Yalçın E, Dönmez S, Kaymaz K, Özdemir G, Özgörür Z, Balcı D, Aslan B, Çakır M. 2008. Vicia faba L. (Fabaceae) kök ucu hücrelerinde fenol tarafindan teşvik edilen sitotoksisitenin belirlenmesi. SDÜ Fen Dergisi (E-Dergi) 3(2): 139-148.

Demirel S, Zamani A. 2002. MN tekniği ve kullanım alanları. Genel Tip Dergisi, 12(3): 123-127.

Duffaud F, Orsiere T, Villani P, Pelissier AL, Volot F, Favre R, 1997. Comparison between micronucleated lymphocytes rates observed in healthy subject and cancer patients. Mutagenesis, 12: $227-231$

Ergene Gözükara S, Çavaş T, Aymak C, 2001. Cypermethrin'in Oreochromis niloticus (L.,1758) üzerindeki genotoksik etkilerin mikronükleus testi ile araştırılması. XI. Ulusal Su Ürünleri Sempozyumu, 2: 765-771.

Ergene S, Kaya Ş, Dürgen A, Uçar A, Erkek M, Ergene M, Könen AS, Özbaba O, Önder H, 2012. Mersin rehabilitasyon merkezinde tedavi altında bulunan yaralı deniz kaplumbağalarının hematolojik ve biyokimyasal özelliklerinin incelenmesi, araştırma makalesi. Anadolu Doğa Bilimleri Dergisi 3(2): 3440.

Fenech M, Chang WP, Kirsch-Volders M, Holland N, Bonassi S, Zeiger E, 2003. Human Micronucleus Project. HUMN Project: Detailed description of the scoring criteria for the cytokinesisblock micronucleus assay using isolated human lymphocyte cultures. Mutation Research-Gen Tox En, 534: 65-75.

Fenech M, 2000. The in vitro micronucleus technique. Mutation Research-Fund Mol, 435: 81-95.

Fenech M, Crott J, Turner J, Brown S, 1999. Necrosis, apoptosis, cytostasis and DNA damage in human lymphocytes measured simultaneously within the cytokinesis-block micronucleus assay: Description of the method and results for hydrogen peroxide. Mutagenesis, 14(6): 605-612.

Fenech M, Morley AA, 1985. Measurement of micronuclei in lymphocytes. Mutation Research, 147: 29-36.

Giri S, Sharma GD, Giri A, Prasad SB, 2002. Genotoxic effects of malathion in chick in vivo micronucleus assay. Cytologia, 67: 53-59.

Gomez-Arroyo S, Díaz-Sánchez Y, Meneses-Pérez MA, VillalobosPietrini R, De León-Rodríguez J, 2000. Cytogenetic biomonitoring in a mexican floriculture worker group exposed to pesticides. Mutation Research, 466: 117-124.

GPT, 2006. Micronucleus assay. GenPharmTox. http://www. genpharmtox.com/ services/ Toxicology/micro_advanced_ test.html (28.05.2012)

Greywe D, Kreutz J, Banduhn N, Krauledat M, Scheel J, Schroeder KR, Wolf T, Reisinger K, 2012. Applicability and robustness of the hen's egg test for analysis of micronucleus induction (HET-MN): Results from an inter-laboratory trial. Mutation Research/Genetic Toxicology and Environmental 
Mutagenesis, 747(1): 118-134.

Griffiths AJF, Miller JH, Suzuki DT, Lewontin RC, Gelbart WM, 2000. An Introduction to Genetic Analysis. W.H. Freeman and Company, New York, USA.

Hamilton JV, Denison MS, Bloom SE, 1983. Development of basal and induced aryl hydrcarbon (benzo(a)pyrene) hydroxylase activity in the chick embryo in ovo. Proceedings of the National Academy of Sciences of the United States of America, 80: $3372-3376$

Heddle JA, Cimino MC, Hayashi M, Romagna F, Shelby MD, Tucker JD, Vanparys P, MacGregor JT, 1991. Micronuclei as an index of cytogenetic damage: Past, Present, and, future. Environmental and Molecular Mutagenesis, 18: 277-291.

Hothorn LA, Reisinger K, Wolf T, Albrecht P, Fieblinger D, Liebsch M, Pirow R, 2013. Statistical analysis of the hen's egg test for micronucleus induction (HET-MN assay). Mutation Research, 757: 68-78.

Jelinek R, 1977. The chick embryotoxicity screening test (CHEST). In: Methods in Prenatal Toxicology. Neubert, D., Merker, H.J. and Kwasigrooh, T.E. (eds.), Georg Thieme, Stutgart, pp. 381-386.

Jena GB, Bhunya SP, 1994. Mutagenicity of an organophosphate insecticide acephate-an in vivo study in chicks. Mutagenesis 9 (4): 319-324

Jena GB, Bhunya SP, 1992. Thirty day genotoxicity study of an organophosphate insecticide, monocrotophos, in a chick in vivo test system. In vivo 6(5): 527-530.

Jena GB, Kaul CL, Ramarao P, 2002. Genotoxicity testing, a regulatory requirement for drug discovery and development: impact of ICH guidelines. Indian Journal of Pharmacology, 34: 86-99.

Kemper FH, Luepke NP, 1986. Toxicity testing by the hen's egg test (HET). Food Chemical Toxicology, 24(6/7): 647-648.

Kirsch-Volders M, Fenech M, 2001. Inclusion of micronuclei in non-divided mononuclear lymphocytes and necrosis/apoptosis may provide a more comprehensive cytokinesis block micronucleus assay for biomonitoring purposes. Mutagenesis, 16(1): 51-58.

Kirsch-Volders M, Elhajouji A, Cundari E, Van Hummelen P, 1997. The in vitro micronucleus test: a multi-endpoint assay to detect simultaneously mitotic delay, apoptosis, chromosome breakage, chromosome loss and non-disjunction. Mutation Research, 392(1-2): 19-30.

Könen S, 2007. Trifluralin ve askorbik asit kombinasyonlarının Oreochromis niloticus üzerindeki genotoksik ve antigenotoksik etkilerinin mikronükleus testi kullanılarak araştırılması. Mersin Üniversitesi Fen Bilimleri Enstitüsü, Yüksek lisans Tezi, Mersin.

Laffon B, Pasaro E, Mendez J, 2001. Genotoxic effects of styrene7,8- oxide in human white blood cells: comet assay in relation to the induction of sister-chromatid exchanges and micronuclei. Mutation Research, 491:163-172.

Lucas AM, Jamroz C, 1961. Atlas of Avian Hematology. Agriculture Monograph 25, United States Department of Agriculture, U.S. Government Printing Office, Washington, DC.

Luepke NP, 1985. Hen's egg chorioallantoic membrane test for irritation potential. Food Chemical Toxicology, 23: 287-291.

MacGregor TJ, Heddle AJ, Hite M, Margolin HB, Ramel C, Salamone MF, 1987. Guidelines for the conduct of micronucleus assays in mammalian bone marrow erythrocytes. Mutation Research, 189: $103-12$.
Marques SM, Antunes SC, Pissarra H, Pereira ML, Gonçalves F, Pereira R, 2009. Histopathological changes and erythrocytic nuclear abnormalities in Iberian green frogs (Rana perezi Seoane) from a uranium mine pond. Aquatic Toxicology, 91(2): 187-195.

Mateuca R, Lombaert N, Aka PV, Decordier I, Kirsch-Volders M, 2006. Chromosomal changes: Induction, detection, methods and applicability in human biomonitoring. Biochimie, 88: 1515-31.

Matson CW, Palatnikov G, Islamzadeh A, Mcdonald TJ, Autenrieth RL, Donnelly KC, Bickham JW, 2005. Chromosomal damage in two species of aquatic turtles (Emys orbicularis and Mauremys caspica) inhabiting contaminated sites in Azerbaijan. Ecotoxicology, 14(5): 513-525.

Mavournin HK, Blakey HD, Cimino CM, Salamone FM, Heddle AJ, 1990. The in vivo micronucleus assay in mammalian bone marrow and peripheral blood: A report of the U.S. Environmental Protection Agency Gene-Tox Program. Mutation Research, 239: 29-80.

Monarca S, Feretti D, Zanardini A, Moretti M, Villarini M, Spiegelhalder B, Zerbini I, Gelatti U, Lebbolo E, 2001. Monitoring airborne genotoxicants in the rubber industry using genotoxicity tests and chemical analyses. Mutation Research, 490: 159-169.

Müller W-U, Streffer C, 1994. Micronucleus assays. In: Advances in Mutagenesis Research. Obe, G. (ed.), Vol 5, SpringerVerlag, pp. 1-134.

Neumann NJ, Hölzle E, Lehmann P, Rosenbruch M, Klaucic A, Plewig G, 1997. Photo hen's egg test: A model for phototoxicity. British Journal of Dermatology, 136: 326-330.

Nishigori H, Mizuura M and Iwatsuru M, 1992. The hen's fertile egg screening test (HEST): A comparison between the acute toxicity for chick embryos and rodents of 20 drugs. Cell Biology and Toxicology, 8 (4): 255-265.

Öcal A, 2012. İnsan periferik kan lenfositlerinde Hypericum heterophyllum vent. türünün mikronükleus, mitotik indeks ve replikasyon indeksi üzerine etkileri. Bozok Üniversitesi Fen Bilimleri Enstitüsü, Yüksek Lisans Tezi, Yozgat.

Özdemir F, Kayaaltı Z, Kaya-Akyüzlü D, 2015. Ksenobiyotiklerin DNA üzerindeki toksik etkileri ve toksikogenetik. Marmara Pharmaceutical Journal, 19: 246-251.

Özparlak H, 2006. Yumurtaya verilen organik insektisit fipronilin tavukların embriyonik ve kuluçka sonu erken dönem gelişimi üzerindeki zararlı etkilerinin belirlenmesi. Selçuk Üniversitesi Fen Bilimleri Enstitüsü, Doktora Tezi, Konya.

Özparlak H, 2008. Organik insektisit fipronilin genotoksik etkilerinin tavuk yumurtası mikronukleus testi ile belirlenmesi. 19. Ulusal Biyoloji Kongresi Özet Kitabı (23-27 Haziran, Trabzon), 561-562.

Özparlak H, 2015. Tavuk embriyolarının embriyotoksisite testlerinde kullanımı. Selçuk Üniversitesi Fen Fakültesi Fen Dergisi, 40: 13-22.

Özparlak H, Arslan A, Güler GÖ, 2011. Organik insektisit fipronilin genotoksik etkilerinin civciv mikronukleus test sisteminde belirlenmesi. Selçuk Üniversitesi Fen Fakültesi Fen Dergisi, 37: $1-8$.

Parlak H, Arslan ÖÇ, Boyacıŏglu M, Karaaslan MA, 2011. Ekotoksikoloji. Ege Üniversitesi Basımevi, İzmir, 339 s.

Preston W, Bender AMA, Brewen JG, Carrano AV, Heddle JA, McFee AF, Wolff S, Wassom JS, 1981. Mammalian in vivo and in vitro cytogenetic assays: A report of the U.S. EPA's 
Gene-Tox Program. Mutation Research, 87: 143-88.

Purchase IFH, Longstaff E, Ashby J, Styles JA, Anderson D, Lefevre PA, Westwood FR, 1978. An evaluation of 6 shortterm tests for detecting organic chemical carcinogens. British Journal of Cancer, 37: 873-959.

Rajaguru P, Fairbairn LJ, Ashby J, Willington MA, Turner S, Woolford LA, Chinnasamy N, Rafferty JA, 1999. Genotoxicity studies on the azo dye direct red 2 using the in vivo mouse bone marrow micronucleus test. Mutation Research, 444: 175-180.

Rosenbruch M, Holst A, 1990. The chick embryo yolk-sac blood vessel system as an experimental model for irritation and inflammation. Toxicology In Vitro, 4(4/5): 327-331.

Savage JRK, 2000. Micronuclei: Pitfalls and problems. Atlas of Genetics and Cytogenetics in Oncology and Haematology. http://www.infobiogen.fr/ services/chromcancer/Deep/ MicronucleiID20016.html (28.05.2012)

Shimizu N, Itoh H, Utiyama H, Wahl GM, 1998. Selective entrapment of extrachromosomally amplified DNA by nuclear budding and micronucleation during $\mathrm{S}$ phase. The Journal of Cell Biology, 140: 1307-1320.

Stopper H, Müler SO, 1997. Micronuclei as a biological endpoint for genotoxicity: A Minireview. Toxicology In Vitro, 11: 661667.

USEPA, 1996. In vivo mammalian cytogenetics test: Erythrocyte micronucleus assay. Health effects test guidelines EPA OPPTS 870. 5395. U.S. Environmental Protection Agency, Washington, USA. http://www.epa.gov/opptsfrs/publications/ OPPTS_Harmonized/870_Health_Effects_Test_Guidelines/ Series/870-5395.pdf (28.05.2012)

Üstün F, 2007. Albendazol'ün olası genotoksisitesi üzerine askorbik asitin etkisi. İstanbul Üniversitesi Sağlık Bilimleri Enstitüsü, Doktora Tezi, İstanbul.

Vanparys P, Vermeiren V, Sysmans M, Temmerman R, 1990. The micronucleus assay as a test for the detection of aneugenic activitiy. Mutation Research, 244: 95-103.

Von Ledebur MM, Schmid W, 1973. The micronucleus test: Methodological aspects. Mutation Research, 19: 109-17.

Vural N, 2005. Toksikoloji. Ankara Üniversitesi Eczacılık Fakültesi Yayınları, Ankara, $659 \mathrm{~s}$.

Waters MD, Stack HF, Brady AL, Lohman PHM, Haroun L, Vainio $\mathrm{H}, 1988$. Use of computerized data listings and activity profiles of genetic and related efects in the review of 195 compounds. Mutation Research, 205: 295- 312.

Wolf T, Luepke NP, 1997. Formation of micronuclei in incubated hen's eggs as a measure of genotoxicity. Mutation ResearchGen Tox En, 394: 163-175.

Wolf T, Niehaus-Rolf C, Luepke N-P, 2002. Some new methodological aspects of the hen's egg test for micronucleus induction (HET-MN). Mutation Research-Gen Tox En, 514: 59-76.

Wolf T, Niehaus-Rolf C, Luepke N-P, 2003. Investigating genotoxic and hematotoxic effects of $N$-nitrosodimethylamine, $\mathrm{N}$-nitrosodiethylamine and $\mathrm{N}$-nitrosodiethanolamine in the hen's egg-micronucleus test (HET-MN). Food and Chemical Toxicology, 41: 561-573.

Wolf T, Niehaus-Rolf C, Banduhn N, Eschrich D, Scheel J, Luepke N-P, 2008. The hen's egg test for micronucleus induction (HET-MN): Novel analyses with a series of well-characterized substances support the further evaluation of the test system. Mutation Research, 650: 150-164.
Yırtıcı Ü, 2007. Tartrazinin Cyprinus carpio'daki genotoksik etkisinin mikronükleus yöntemiyle araştırılması. Erciyes Üniversitesi Fen Bilimler Enstitüsü, Yüksek Lisans Tezi, Kayseri.

Zeiger E, 2004. History and rationale of genetic toxicology testing: an impersonal, and sometimes personal. Environmental Molecular Mutagenesis, 44: 363-371. 